\title{
Managerial Performance Improvement Through Budget Participation With Moderation Variables In Public Companies
}

\author{
Kusmuriyanto $^{1}$, Achmad Slamet ${ }^{2}$, Trijoko Raharjo $^{3}$, Heri Yanto ${ }^{4}$ \\ \{kusmuriyanto@yahoo.com ${ }^{1}$ \} \\ Universitas Negeri Semarang ${ }^{1,2,3,4}$
}

\begin{abstract}
Budget participation is one form of involvement of managers, both top-level managers, and lower-level managers in order to realize the objectives of business entities. This study aims to examine the effect of budgeting participation on managerial performance, both directly and indirectly through a culture of organizational achievement, leadership style, environmental uncertainty, and organizational commitment as a mediating variable. The object of this research is the managers of Regional Owned Enterprises (BUMD) in Central Java \& DIY, Collecting data using questionnaires with 107 respondents. Data analysis techniques use path analysis. The results showed that there were 12 analyzes of direct, indirect or total influence. In the analysis the highest total coefficient of influence is on the direction of the leadership style causality path, on budget participation, and organizational culture. Whereas the lowest total influence coefficient is in the direction of the causality path of environmental uncertainty towards budget participation, and organizational culture. Budget participation is an effort to build togetherness of all members (leaders and employees), foster organizational culture, and organizational commitment to improve managerial performance by paying attention to leadership style and environmental uncertainty. The study of budget participation and managerial performance in various entities is still relevant in the future, because related to human behavior which is always different according to the dimensions of space and time
\end{abstract}

Keywords: Budget Participation, Outstanding Organizational Culture, BUMD

\section{Introduction}

The company as a business entity in making an effort to utilize economic resources (wealth) owned and trying to multiply that wealth. Therefore the company is often referred to as the institution of creating wealth (wealth creating institution [1]. With the wealth that was successfully created, the business entity will try to achieve the goal and provide welfare to the interested parties (stakeholders)

The performance of a business entity can be said to be the estuary of activities carried out jointly by various elements (resources) contained within a business entity. The success of a business entity in achieving its objectives is inseparable from the ability of managers Managerial performance is a process of implementing management functions, in which there is interaction between superiors and subordinates in planning, directing, controlling resources to realize common goals 
In a business entity, managerial performance can be associated with its participation in budgeting. Participation in budgeting is a level of how much involvement and strength of managers influence budgeting [2]. The involvement of subordinates in budget participation increases the trust of subordinates, a sense of control, and ego-involvement in the organization, and has a commitment to implement it, which in turn will lead to increased performance [2].

This research is focused on BUMDs in Central Java \& DIY having a very strategic position in the national and regional economies, and community welfare. BUMD management is still not optimal and is still trapped in bureaucratic work patterns rather than as a customer satisfaction oriented company, and there are mismanagement practices that lead to inefficiencies and fraud in managing BUMD (Review of the 2014 BPKP). This has an impact on managerial performance, most of the BUMD is not optimal. Management and development of BUMD has not implemented good corporate governance.

The effect of budget participation on managerial performance is an interesting factor in management accounting research. Brownell (1982b) mentions two reasons, namely (a) participation is assessed as a managerial approach that can improve the performance of organizational members, and (b) various studies that examine the relationship between participation and performance outcomes are conflicting. The first research related to budget participation was put forward by Argyris in 1952 stating the need for subordinates to be given the opportunity to participate in the budgeting process (Covaleski et al. (2003) and Farahmita (2017)). Furthermore, this research has expanded to a broader horizon with a large number of empirical studies on the subject of participatory budgeting that are motivated by theories in the fields of economics, psychology, and sociology (Covaleski et al, 2003).

One aspect of leadership that influences managerial performance is leadership style. Leadership style is related to the way used by managers to regulate, influence employees in order to achieve company goals. Besides that, the organizational culture has a strategic role in the success of the organization to build managerial performance and can encourage the organization to grow and develop. The role of organizational culture itself is as a tool to determine the direction of the organization, directing what is and cannot be done, how to process and allocate organizational resources to deal with internal and external problems.

\section{Literature Review}

\subsection{Contingency Theory}

Islam and $\mathrm{Hu}$ (2012) suggest that contingency theory is an approach to studying organizational behavior where explanations are given about how contingent factors such as technology, culture and external environment influence the design and function of the organization. However, it must be realized that the assumption underlying the contingency theory is that there is no one type of organizational structure that applies to all organizations. Regarding budgeting, Govindarajan (1986a) said that the contingency approach should be used to identify various conditions that make participatory budgets more effective.

\subsection{Budget Participation}

The budget is an accounting tool that is generally used by business entities to plan, control and supervise business activities in realizing the business entity's goals. Budgeting involves many parties, from top to bottom level management. Brownell (1982) broad participation is 
basically an organizational process, where individuals are involved and have an influence in making decisions that have a direct influence on these individuals

\subsection{Managerial Performance}

Managerial performance is a factor that supports the effectiveness of business entities and will affect the performance of business entities. According to Mahoney (1963) the performance of managers is based on the ability of managers to carry out their managerial duties. Managerial performance includes the ability of managers in: planning, investigation, coordination, evaluation, supervision, staff selection, negotiation, representation and overall performance has been established.

\subsection{Leadership Style}

According to Robbin (2006) leadership is the ability to influence groups towards achieving goals. Thus leadership is a way of how a leader manages and coordinates a company or organization to achieve the expected goals. The main requirement of a leader is to be able to achieve good relations and cooperation and be able to carry out tasks well in order to achieve common goals. According to Tjiptono and Diana (1998) there are five leadership styles, namely: (1) Autocratic Leadership, (2) Democratic Leadership, (3) Participatory Leadership, (4) Objective Oriented Leadership, (5) Situational Leadership

\subsection{Achieving Organizational Culture}

According to Hofstede (1994) culture is the overall pattern of thoughts, feelings and actions of a social group that distinguishes it from other social groups. According to Luthans (1998) in Sudarmadi (2007), organizational culture is norms and values that direct the behavior of organizational members. Whereas Tan (20012) in Wibowo (2012) the organizational culture of norms consists of beliefs, attitudes, core values, and behavioral patterns carried out by people in the organization. According to Tan (2002) shared values that become cultural dimensions of achievement: (1) results oriented (result oriented), (2) high customer service, (3) innovation, (4) honesty, (5) appreciation, (6) Response to change, (6) Accountability, (7) Big desire

\subsection{Environmental Uncertainty}

The perceived environmental uncertainty is the most important factor in the company because it makes it difficult for companies to make predictions (Govindarajan, 1986). Environmental uncertainty is an individual limitation in assessing the probability of failure or success of a decision that has been made (Duncan, 1972). Environmental uncertainty is a situation of someone who is constrained to predict the situation around him so he tries to do something to deal with the uncertainty of the environment (Luthans, 1998). In conditions of high uncertainty, individuals find it difficult to predict failures and successes from decisions made (Fisher, 1996)

\subsection{Organizational Commitment}

Robbins (2003) defines organizational commitment as the level at which employees identify with the organization and its purpose, and the desire to maintain membership in the organization. Based on the definition of commitment, organizational commitment is seen as a value orientation towards the organization which shows that everyone (member) will think deeply about and prioritize their work and organization. Every member of the organization will try to give all the effort he has in order to help the organization achieve its goals. . Allen and 
Meyer (1990) proposed three forms of organizational commitment, namely: (1) Affective Commitment, (2) Continuous Commitment, (3) Normative Commitment

\section{Research Method}

The population and sample in this study were managers / section heads / Section Heads / branch heads / services that were the worst in Central Java and DIY BUMD. Data collection techniques used were questionnaires / questionnaires. To get the research data that will be processed is done by sending questionnaires / questionnaires randomly to 240 respondents. Questionnaires for breastfeeding cases and can be processed as many as 107 respondentsThe variables in this study consisted of 7 variables consisting of: (1) Managerial Performance, (2) Budget Participation, (3) Environmental Uncertainty, (4) Leadership Style, (5) Organizational Commitment, (6) Achieving Organizational Culture. The study of research variables using a linkert scale with an alternative score of 1 to a score of 5.The data analysis method used is descriptive analysis and path analysis

\section{Results and Discussion}

\subsection{Results of the Intervening Variable Goodness of Fit Test}

Model testing is done by using inferential statistics, through path analysis. The results of path analysis using the help of AMOS release 19.0 application software produce a Path Diagram between the research variables along with indicators of the Goodness of Fit Research Model in the Fit Model Output as shown in Figure 1

Next the results of path analysis using the help of AMOS release 19.0 application software, produce path coefficient output in standardized estimate, CR value, and probability value (pvalue), for theinfluence of Organizational Culture, Leadership Style, Environmental Uncertainty on Budget Participation as shown in the following figure 1

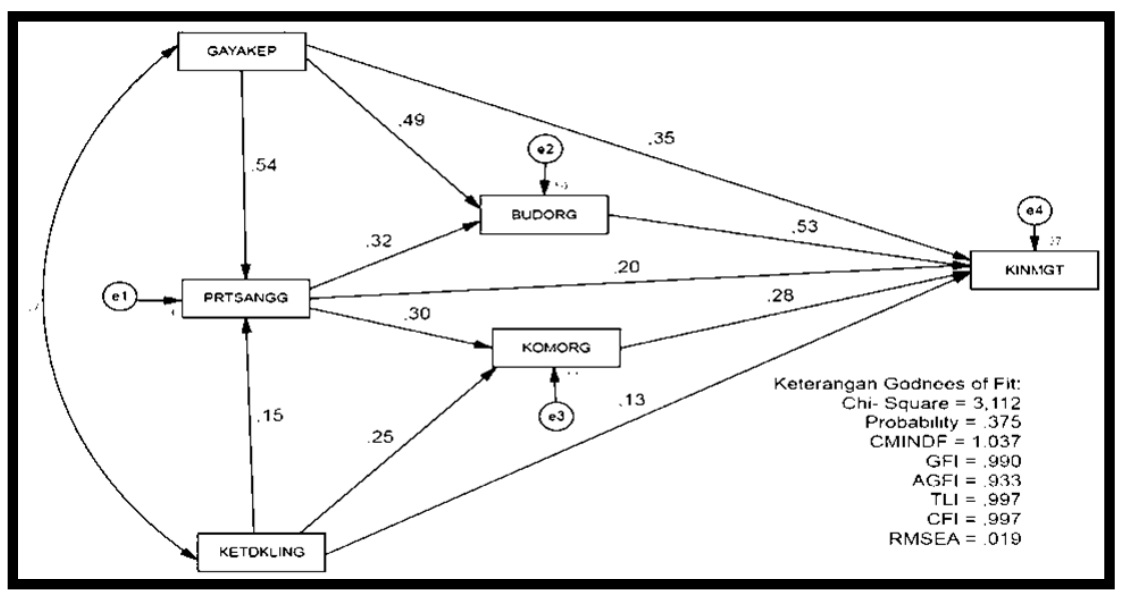

Figure 1. Goodness of Fit Research Model Path Chart 
Effect of Leadership Style on Managerial Performance. Based on the results of the study, the test of H1 which shows that there is an influence of the leadership style. This gives the meaning that the better the leadership style will be followed by an increase in managerial performance. Empirically, based on the CFA test and hypothesis, this finding illustrates that the better the manager's intensity in discussing with subordinates for advice, treating subordinates in the same way, personal attention in subordinate promotions, feeling confident in making decisions, taking decisions does not involve subordinates, limiting impersonal relationships with subordinates so that this has an impact on improvement manager's ability to plan, coordinate, supervise and regulate staff that supports the effectiveness of business entities. These findings are motivated by managerial performance as a representation of the manager's ability to carry out managerial tasks that are measured by how managers carry out planning, investigation and supervision, which are important factors. The ability of leaders is used as a reference for how line managers do their jobs. This is clearly expressed in contingency theory that cultural factors influence organizational behavior (Islam and $\mathrm{Hu}, 2012$; Nimtrakoon, 2009).

Effect of leadership style on budget participation. Based on this fact, $\mathrm{H} 2$ is proposed in the study, which states that leadership style has a significant positive effect on budget participation. Based on the results of the study, the $\mathrm{H} 2$ test showed that there was an influence of the leadership style on budget participation accepted statistically. This gives the meaning that empirically improving leadership style will be followed by increased budget participation. Empirically, based on the CFA test and hypothesis, this finding illustrates that the better the manager's intensity in discussing with subordinates for advice, treating subordinates in the same way, personal attention in subordinate promotions, feeling confident in making decisions, taking decisions does not involve subordinates, limiting impersonal relations with subordinates, then this has an impact on the better budget participation activities which include always being involved in budgeting in all fields according to responsibility, contributions of employee thoughts are important factors in budgeting, employee supervisors always ask for opinions and suggestions when employees budget is prepared, if there are things that are not logical related to the employee's budget always give suggestions and suggestions, employees always give opinions and / or proposals at the time of budgeting.

Effect of Leadership Style on Organizational Culture. Based on this fact, H3 is proposed in the study, which states that the leadership style has a significant positive effect on budget participation. Based on the results of the H3 study which shows that there is an influence on the style of leadership towards organizational culture is accepted statistically. Empirically, based on the CFA test and hypothesis, this finding illustrates that the better the manager's intensity in discussing with subordinates for advice, treating subordinates in the same way, personal attention in subordinate promotions, feeling confident in making decisions, making decisions does not involve subordinates, limiting impersonal relations with subordinates, then this will be followed by an increase in the encouragement of the development of innovative ideas, tolerance of risk limits, assessment of standardized and fair work, fair sanctions or penalties, caring and respect for people and results, attention and appreciation for those who excel, work awareness and the best members, share information, respect leaders as role models of work.

Effects of environmental uncertainty on budget participation. Based on this fact, the H.5 is proposed in the study, which states that environmental uncertainty significantly has a positive effect on organizational commitment. Based on the results of the H1 study which shows that there is an influence of leadership style on managerial performance, it is rejected statistically. Based on the CFA test and hypothesis, these findings provide meaning that empirically that the 
more managers feel they have the best method, not to enter into control and influence decisions, beliefs about adjustments to face the changes that occur, actions will complete the work in accordance with the budget, knowledge of how to work in accordance with information, confidence in how work must be done, apparently does not have an impact on providing opportunities for employees to always be involved in budgeting in all fields according to responsibility, contributions of employee thoughts are important factors in budgeting, employee supervisors always ask for opinions and proposals of employees when the budget is prepared, if there are things that are illogical related to the employee's budget always give suggestions and suggestions, employees always give opinions and / or proposals at the time of budgeting.

Effect of Environmental Uncertainty on Organizational Commintments. Based on this fact, the H6 is proposed in the study, which states that budget participation does not significantly have a positive effect on managerial performance. Based on the results of the $\mathrm{H} 7$ study which showed that there was an influence of leadership style on managerial performance received statistically. Based on the CFA test and hypothesis, the findings give meaning that empirically the more managers feel they have the best method, do not enter the control and influence decisions, beliefs about adjustments to face the changes that occur, actions will complete the work in accordance with the budget, knowledge of how to work according to information, confidence in how work should be done, it can have an impact on employees' thinking and feeling that employees have their thoughts and feelings will accept the negative consequences of leaving this company to be scarcity, feel guilty if they leave this company at this time, they think that this company has the right to get employee loyalty, this company has a lot of personal meaning for employees, many lives will be disrupted if leaving the company, this company is very much meritorious to employees

Effect of Budget Participation on Managerial Performance. Based on the results of the H7 study which showed that there was an influence of the leadership style on managerial performance, it was rejected statistically. Based on the CFA test and hypothesis, this finding implies that empirically that managers who act on subordinates such as providing opportunities for employees to always be involved in budgeting in all fields according to responsibility, the contribution of employee thoughts is an important factor in budgeting, employee supervisor always asking for opinions and suggestions from employees when the budget is prepared, if there are things that are not logical related to the employee's budget always give suggestions and suggestions, the employee always gives opinions and / or proposals at the time of budgeting, it does not affect the increase manager's ability to plan, coordinate, supervise and regulate staff that supports the effectiveness of business entities.

Effects of Budget Participation on Organizational Commintments. The budget participation path coefficient on organizational commitment in standardized e Based on this fact, then $\mathrm{H} 8$ is proposed in the study, which states that budget participation has a significant positive effect on organizational commitment. Based on the results of the H8 study which showed that there was an influence of leadership style on managerial performance received statistically. Based on the CFA test and hypothesis, this finding implies that empirically that managers who act on subordinates such as providing opportunities for employees to always be involved in budgeting in all fields according to responsibility, the contribution of employee thoughts is an important factor in budgeting, employee supervisor always asking for opinions and suggestions from employees when the budget is prepared, if there are things that are not logical related to the employee's budget always giving suggestions and suggestions, employees always give opinions and / or proposals at the time of budgeting. it can have an impact on employees' thinking and 
feeling that employees have their thoughts and feelings will accept the negative consequences of leaving this company to be scarcity, feel guilty if they leave this company now, they think that this company deserves employee loyalty, this company has a lot personal meaning for employees, many lives will be disrupted if leaving companies,

Effects of Budget Participation on Organizational Culture. Based on this fact, the H9 proposed in the study, which states that budgetary participation is significantly positive effect on organizational culture Based on the results of the $\mathrm{H} 9$ study which shows that there is an influence of leadership style on managerial performance is accepted statistically. Based on the CFA test and hypothesis, this finding implies that empirically that managers who act on subordinates such as providing opportunities for employees to always be involved in budgeting in all fields according to responsibility, the contribution of employee thoughts is an important factor in budgeting, employee supervisor always asking for opinions and suggestions from employees when the budget is prepared, if there are things that are not logical related to the employee's budget always giving suggestions and suggestions, employees always give opinions and / or proposals at the time of budgeting. This has an impact on increasing the impetus for developing innovative ideas, tolerating risk limits, evaluating standard and fair work, sanctions or punishments that are fair, caring and respecting people and their results, attention and appreciation for those who excel, awareness of working and the best members, sharing information, respecting leaders as role models of work.

Effect of Organizational Culture on Managerial Performance. Based on this fact, then H11 is proposed in the study, which states that organizational commitment has a significant positive effect on managerial performance. The organizational commitment path coefficient on managerial performance in the standardized estimate is 0.532 with a CR value of 4.849 or greater than 1.98 and significant in the probability value (p-value) of *** or smaller than the significance level of 5\%. Based on this fact, then $\mathrm{H} 11$ is proposed in the study, which states that organizational commitment has a significant positive effect on managerial performance. Based on the results of the H10 study which shows that there is an influence of leadership style on managerial performance is accepted statistically. Based on the CFA test and hypothesis, these findings provide an empirical meaning that when a company has a culture of increasing impetus for the development of innovative ideas, tolerance of risk limits, standardized and fair work valuations, fair sanctions or punishments, caring and mutual respect people and their results, attention and appreciation for those who excel, awareness of working and the best members, sharing information, respecting leaders as role models of work. This has an impact on improving the ability of managers to carry out planning, coordinating, monitoring and regulating staff that supports the effectiveness of business entities. Regarding managerial performance which is influenced by organization, the approach taken in contingency theory places cultural factors as important factors that influence the organization (Islam and $\mathrm{Hu}, 2012$ ). Approaches to other theories such as Institutionalism consider organizational paradigms to be a unified social system, influenced by the wider symbolic system, culture, and social aspects in which the organization is located (Gudono, 2017). When referring to this understanding, the managerial performance in the organization is very strongly determined by the culture of the organization.

\subsection{Results of Analysis of Direct, Indirect and Total Influences}

Furthermore, the results of path analysis using the help of AMOS release 19.0 application software also resulted in a path coefficient in the standardized estimate, from the direct effect, indirect influence, and total influence, as in the following table 1. 
Table 1. Output Direct, Indirect, dan Total Effect

\begin{tabular}{llrrr}
\hline No & \multicolumn{1}{c}{ Arah Jalur Kausalitas } & Direct Effect & Indirect Effect & \multicolumn{1}{c}{ Total Effect } \\
\hline 1 & GK $\rightarrow$ PA $\rightarrow$ BO & 0,489 & 0,17064 & 0,65964 \\
2 & GK $\rightarrow$ PA $\rightarrow$ KM & 0,353 & 0,10584 & 0,45884 \\
3 & GK $\rightarrow$ PA $\rightarrow$ KO & & 0,16038 & 0,16038 \\
4 & GK $\rightarrow$ BO $\rightarrow$ KM & 0,353 & 0,260148 & 0,613148 \\
5 & PA $\rightarrow$ BO $\rightarrow$ KM & 0,196 & 0,168112 & 0,364112 \\
6 & GK $\rightarrow$ PA $\rightarrow$ BO $\rightarrow$ KM & 0,353 & 0,007463 & 0,360463 \\
7 & KL $\rightarrow$ PA $\rightarrow$ KO & 0,252 & 0,045144 & 0,297144 \\
8 & KL $\rightarrow$ PA $\rightarrow$ KM & 0,134 & 0,029792 & 0,163792 \\
9 & KL $\rightarrow$ PA $\rightarrow$ BO & & 0,048032 & 0,048032 \\
10 & KL $\rightarrow$ KO $\rightarrow$ KM & 0,134 & 0,070308 & 0,204308 \\
11 & PA $\rightarrow$ KO $\rightarrow$ KM & 0,196 & 0,082863 & 0,278863 \\
12 & KL $\rightarrow$ PA $\rightarrow$ KO $\rightarrow$ KM & 0,134 & 0,000263 & 0,134263 \\
\hline
\end{tabular}

Notes: BO: Organization Culture $G K$ : leadership style, $K L$ : Environmental Uncertainty $P A$ : participation budget, $K O$ : organizational commitment $K M$ : managerial performance

Based on Table 4.2 above it is known, there are 12 analyzes of direct, indirect or total influence. In the analysis the highest total coefficient of influence is in the direction of the leadership style causality path (GK) participation budget (PA) organizational culture (BO) with the total influence coefficient of 0.65964 , then followed by the direction of the leadership style causality path $(\mathrm{GK})$ organizational culture $(\mathrm{BO})$ managerial performance $(\mathrm{KM})$ with a total effect coefficient of 0.65964 . Furthermore, for the lowest total effect coefficient is in the direction of the causality path of environmental uncertainty (budget) "budget participation (PA)" organizational culture (BO) with the total effect coefficient amounting to 0.048032 , then followed by the $(\mathrm{KL}) \diamond$ budget participation (PA) organizational commitment $(\mathrm{KO})$ managerial performance $(\mathrm{KM})$ with the total effect coefficient of 0.134263 .

\section{Conclussion}

The results showed that there were 12 analyzes of direct, indirect or total influence. In the analysis the highest total coefficient of influence is on the direction of the leadership style causality path, on budget participation, and organizational culture. Whereas the lowest total influence coefficient is in the direction of the causality path of environmental uncertainty towards budget participation, and organizational culture 


\section{Reference}

[1] Mulyadi dan Johny Setiawan,1999, "Sistem Peraencanaan \& Pengendalian Manajemen : Sistem Pelipatganda Kinerja Perusahaan" Yogyakarta, Aditya Media

[2] Shields and Shields (1998). Antecedents of participative budgeting. Accounting, Organisations and Society, Vol. 23, No.1, pp 49-76

[3] Anissa, Dakhli, 2010, "Budgetary Participation, Locus Of Control And Job Satisfaction In Tunisia", halshs-00459229, version 1 - 3 Mar 2010

[4] Adeyemi, Semiu Babatunde, Comfort E.Omorogbe, E, Comfort E. Omorogbe, “The Influence

[5] of Power Distance in a Participative Budgeting Environment and Information Technology in Nigeria”, Economics and Finance Review Vol. 2(5) pp. 91 - 99, July, 2012 ISSN: 2047 - 0401, Available online at http://www.businessjournalz.org/efr 91

[6] Boujelbene, Mohamed Ali and Habib Affes, The effect of environmental uncertaint and budgetary participation on performance and job Satisfaction evidence from the hotel industry, African Journal of Hospitality, Tourism and Leisure Vol. 2 (2) - (2012) ISSN: 2223-814X

[7] Chi, Hsin Kuang, Huery Ren Yeh. Chiou Huei Yu, The Effects of Transformation Leadership, Organizational Culture, Job Satisfaction on the Organizational Performance in the Non-profit Organizations

[8] Chongruksut, Wipa." Organizational Culture and the Use of Management Accounting" Innovations in Thailand. RU. Int. J. vol. 3(1), 2009,- 113

[9] Dr Desmond Yuen, "Antecedents of Budgetary Participation: Enhancing Employees

[10] Job Performance”, University of Macau, Taipa, Macau. e_mail : desmondy@umac.mo

[11] Ehtesham, Ul Mujeeb, Tahir Masood Muhammad, Shakil Ahmad Muhammad "Relationship between Organizational Culture and Performance Management Practices: A Case of University in Pakistan",

[12] Etemadi, Hossein, Zahra Dianati Dilami, Mohammad S. Bazaz, Ravi Parameswaran, "Culture, management accounting and managerial performance: Focus Iran", Advances in Accounting, incorporating Advances in International Accounting 25 (2009) 216-225, journal homepage: www.elsevier.com/locate/adiac

[13] Feng-Yu Nia , Chin-Chun Sub, Shao-Hsi Chungc,Kuo-Chih Cheng, “Budgetar Participation's Effect on Managerial Outcomes: Mediating Roles of Self Efficacy and Attitudes toward Budgetary Decision Makers"

[14] Haryanti, Ida Binti Mohd Noor and Radiah Othman," "Budgetary Participation: How It Affects Performance And Commitment", Accountancy Business and the Public Interest 2012

[15] Horngren, Datar, dan Foster, 2008, “Akuntansi Biaya : Pendekatan Manajerial”, (terjemahan), Desi Adhariani, Jakarta: Penerbit PT Indeks

[16] Ikhsan, Arfan, Muhammad Ishak, 2005, “Akuntansi Keperilakuan”, Jakarta : Penerbit Salemba Empat

[17] Holmes S. dan Marsden. (1996). "An Exploration of the spoused Organizational Culture of Public Accounting Firms", Accounting Horizons, September.

p 26-53

[18] Hosen, Yosef Kalefa, et el, 2011, "The Influence of Culture on the Relationship Between Level of Partici[ation Budgeting and Firm Performance in the Context of Libya", Asian Journal of Business Management Studies 2 (2) 84-93, ISSN 2222-1387 IDOSI Publication,2011

[19] Joedo, Hari S Malang, dan Rian Nugroho, 2006, "Reinventing BUMD Badan Usaha Milik Daerah: Kunci Sukses Mengembangkan BUMD Produkrif dan Profesional", Jakarta: PT Elex Media Komputindo

[20] Kusdi, 2011, "Budaya Organisasi: Teori, Penelitian, dan Praktik", Jakarta : Penerbit Salemba Empat

[21] Kren, Leslie.” Budgetary Participation and Managerial Performance: The Impact of Information and Environmental Volatility" The Accounting Review, Vol. 67, No. 3. (Jul., 1992), pp. 511-526. 
http://links.jstor.org/sici?sici=0001-

4826\%28199207\%2967\%3A3\%3C511\%3ABPAMPT\%3E2.0.CO\%3B2-Q

[22] Libby, Theresa, 2008: The Influence of voice and explanation on performance in a participative budgeting setting, Accounting Organization Society, 24 (1999) $125 \pm 137$

[23] Lako, Andreas, 2004, "Keoemimpinan dan Kinerja Organisasi : Isu, Teori, dan Solusi" Yogyakarta. Penerbit Amara Books

[24] López, Maria A. Leach, William W. Stammerjohan, Kyoo Sang Lee, "Budget Participation and Job Performance of South Korean Managers Mediated by Job Satisfaction and Job Relevant Information", 7th Global Conference on Business \& Economics ISBN : 978-0-9742114-9-7

[25] Lopez, , Maria A Leach, Wiliam W S and. John T Rigsby Jr, 2008: An Update Budgetary Participant, Locus of Control, and The Effects On Mexican Managerial Perform Job KMtisfaction, The Journal Applied Business Research, Third Quarter 2008 Volume 24, Number 3

[26] Mahjoub. LasKMad Ben and Khamoussi Halioui,"The impact of Budget Participation on Organizational Performance via Competitiveness", International Journal of Contemporary Business Studies Vol: 3, No: 6. June, 2012 ISSN 2156-7506 Available online at http://www.akpinsight.webs.com

[27] Mah'd1, Osama et al, “ The Impact of Budgetary Participation on Managerial Performance: Evidence from Jordanian University Executives” Journal of Applied Finance \& Banking, vol. 3, no. 3, 2013, 133-156 ISSN: 1792-6580 (print version), 1792-6599 (online)Scienpress Ltd, 2013

[28] Marcoulides, George A. and Ronald H. Heck, "Organizational Culture and Performance: Proposing and Testing a Model” Organization Science, Vol. 4, No. 2. (May, 1993), pp. 209-225. http://links.jstor.org/sici?sici=1047 7039\%28199305\%294\%3A2\%3C209\%3AOCAPPA\%3E2.0.CO\%3B2-4

[29] Mardiasmo. 2002. Akuntansi Sektor Publik. Penerbit Andi. Yogyakarta

[30] Milani, K. 1975. The Relationship of Participation in Budget Setting to Industrial Supervisor Performance and Attitude: A Field Study, The Accounting Review, April 274-284.

[31] Nor Saadah binti Khalil, Task Uncertainty, Participative Budget and Performance: The Case of KIC Group of Companies, Thesis, Graduate School of Business Faculty of Business and Accountancy Master of Business Administration The University of Malaya, Malaysia, 2009

[32] Porter, Lyman W., and Steers R.M. 1973. Organizational, Work, and Personal Factors in Employee Turn Over and Absenteeism. Psychological Bulletin. 80 (2): 151-176.

[33] Rivai, Veithzal, Deddy Mulyadi, 2012, "Kepemimpinan dan Perilaku Organisasi” Jakarta : PT Raja GrafindoPersada

[34] Robbins, P. Stephen, 2003. Perilaku Organisasi: Konsep, Kontroversi, dan Aplikasi. Alih Bahasa Handayana Pujaatmika. Edisi Bahasa Indonesia. Jakarta: Prenhalindo.

[35] Sembiring, Masana, 2012, "Budaya Kinerja Organisasi (Perspektif Organisasi Pemerintahan)", Bandung: Fokusmedia

[36] Siagian, Sondang P, 2002. "Kiat Meningkatkan Produktivitas Kerja” Jakarta: Penerbit Rineka Cipta

[37] -------, 2003, “”Teori dan Praktek Kepemimpinan”, Jakarta: Penerbit; Renika Cipta

[38] Subramaniam, Nava, Neal M. Ashkanasy, The Effect of Organisational Culture Perceptions on the Relationship Between Budgetary Participation and Managerial Job-Related Outcomes

[39] Sopiah, 2008, "Perilaku Organisasional", Yogyakarta : Penerbit Andi

[40] Sugioko, Sofian, The Impact of Budget Participation on Job Performance of University Executives: A Study of APTIK-Member Universities in Indonesia, Kasetsart J. (Soc. Sci) $31: 271$ $-279(2010)$

[41] Yuen, Desmond C.Y. and Keith C.C. Cheung, Impact of Participation in Budgeting and Information Asymmetry on Managerial Performance in the MacauService Sector, JAMAR Vol. $1 \cdot$ Number $2 \cdot 2003$ 
[42] Yukl, Gary A, 1989, "Managerial Leadership: A Review of Theory and Research", Journal of Management, Vol 15, No.2, 251-289. 